\title{
FORMATION OF ENGINEERING SPECIALISTS AT UNIVERSITY: ADAPTATION AND LEARNING MOTIVATION PROBLEMS
}

\author{
Natalia Popova $^{1}$, Leonas Tolvaisis ${ }^{1}$, Baiba Briede $^{2}$, Aleksandr Ponomarev ${ }^{1}$ \\ ${ }^{1}$ Ural Federal University, Russia; ${ }^{2}$ Latvia University of Life Sciences and Technologies, Latvia \\ n.v.popova@urfu.ru, ltolvaishis@urfu.ru,baiba.briede@1lu.lv, a.v.ponomarev@urfu.ru
}

\begin{abstract}
During the Fourth Industrial Revolution, the development of society depends on multiple factors, primarily on technologies and the quality of training of modern engineers, including university graduates. The aim of the present study is to elaborate proposals and recommendations for increasing the students' motivation to study at universities and managing problems of their adaptation. This research is based on the following methods: analysis of philosophical, managerial, sociological and pedagogical literature; survey and comparative data analysis. 627 engineering students of the Ural Federal University named after the first President of Russia B. N. Yeltsin (Russia) and 127 students of the Latvia University of Life Sciences and Technologies (Latvia) have been surveyed. The results show that regular research of problems of motivation for learning and adaptation to the future profession at the university is a prerequisite for becoming a highly qualified specialist in the field of engineering. Problem monitoring will contribute to students' adaptation to their future profession as they pursue their curriculum. It has been found that engineering education has different characteristics in various countries. The survey has shown UrFU and LLU students' interest in obtaining a degree in engineering and pursuing the occupations for which they are qualified. At the same time, the role of the university in enhancing motivation and accelerating the adaptation of students should consist in practice-oriented learning, building competencies and personal qualities required in their future profession.
\end{abstract}

Keywords: engineer, students, professional adaptation, learning motivation, education.

\section{Introduction}

In view of the Fourth Industrial Revolution, much depends on technologies and the quality of training of modern engineers, including university graduates. Requirements for engineering and technical specialists are increasing, as modern equipment is introduced at enterprises, increasing speed and complexity of production processes, along with progressive automation and developing remote control systems. At the same time, societies are faced with a contradiction. On the one hand, engineering specialists are trained by educational institutions that aspire to create necessary conditions for building professional and personal competencies. On the other hand, training success is contingent on the student's motivation for a profession and satisfaction with the university life and the studied profession, making it necessary to elaborate and implement programmes of student motivation and adaptation. This contradiction has a significant impact on the formation of engineering specialists in universities of different countries. Firstly, the increasing importance of innovations in economy and rapid change of prevalent technologies dramatically tighten the requirements for the basic education of engineers and for the quality of their intellectual, volitional and organisational abilities. Secondly, a dramatic growth in the role of small and medium-sized innovative companies in the modern high-tech economy increases the demands on integrity, versatility and breadth in engineer training. The engineer again performs the simultaneous roles of scientist, technical expert and head of an enterprise, as their area of responsibility is expanding. Thirdly, the current situation is different from that of the $20^{\text {th }}$ century when the system of universal mass education was created, and every next generation was acquiring increasingly more "formal knowledge" through the school and the university. The classic concept of engineering education that developed in the $18^{\text {th }}$ and $19^{\text {th }}$ centuries and reached its peak in the early $20^{\text {th }}$ century has now regained its relevance [1]. The system of higher professional education is the basis of staffing the economic and scientific potential of any country. It is thus essential to regularly diagnose its real condition and compliance with the current and future needs of society, as well as, in particular, students' motivation to training in technical occupations, including primary motivation for choosing a university, the significance of a future profession (system of professional values), professional plans and expectations of engineering students. It is especially important in drawing up adaptation programmes in universities.

The analysis of theoretical literature on engineering education in various countries and on the formation of engineering specialists at the university shows the relevance of the subject matter for scientists and practitioners around the world. The present research has been organised and conducted drawing on the findings laid out in a number of theoretical studies. First of all, we draw on the World 
Economic Forum 2020 reports that contain the newest data on emerging jobs and top skills in the field of engineering. Jobs for engineers will be created in various fields of activity, including economy, cloud computing and manufacturing [2]. A comparative study by M. Abdulwahed and M.O. Hasna focuses on the role of engineering design in building technological competencies in the Middle East, Asia and Europe [3]. D.L. Saprykin reviews the three-century history of engineering education in Russia, highlights its key turning points, conducts a systematic comparative analysis of parameters, structure and concepts of engineering education in Russia, the leading European states and the USA. He pays particular attention to the emergence of the "physical and technical" model of education in Russia [1]. The study by G.L. Downey, J.C. Lucena, B.M. Moskal et al. is dedicated to the research of global competency and national traditions in defining priority engineering skills [4]. M.N. Dudin, V.V. Bezbank, E.E. Frolova and M.V. Galkin analyse the models of higher education in Russia and the European countries in the early 21 st century, identifying the main directions of their development [5].

A.S. Korobtsov presents factors that determine the quality of engineering education in a competency-based approach, focusing on their relationship with the main structural elements of the educational process. He considers the role and the actual condition of the main factors that determine the quality of engineering education: federal state educational standards, the main curricula of universities, the level of the teaching staff and its motivation, the level of training of applicants and motivation of students, general management of the university, pedagogical technologies applied and integration of science and education [6]. He also proposes a methodology that allows substantiating the number and essence of professional competencies for the practical implementation of the competencybased approach in engineering education [7]. V.I. Vasilyev, A.V. Sharypov, A.V. Savelyev, N.N. Rybin analyse the organisation of student research activities in the context of the development of digital technologies and the general procedure for designing efficient systems of managing research conducted by students of the Polytechnic Institute of the Kurgan State University [8]. V.P. Solovyev and T.A. Pereskokova consider the problems of building personal and social skills of future engineers during their studies and analyse the life goals of technology students [9]. The problems of self-directed learning of the LLU and UrFU engineering students in the context of the Fourth Industrial Revolution have been analysed by us in a separate article [10].

As regards the characteristic features of engineering education in Europe and Russia, the following should be noted.

Engineering education in Europe is divided in two historical traditions. The practical tradition is represented by technical schools using a skill-based method. The theoretical tradition is represented by universities that draw on a scientific method in their work. The United Kingdom and Ireland model is based on the key role of practitioners, industry and political priorities [11]. The continental historical tradition of engineering education is based on research and the leading role of technical universities in scientific discovery. Within the German engineering education systems there exists a distinction between technical engineers trained by technical universities for industrial production and graduate engineers trained by research-oriented universities to work in management, design and research. The French model of engineering education combines practical and scientific approaches: engineering education prepares reputable and socially active actors rather than mere technical executors [12]. Broadly skilled "global engineers" are trained to work as managers, whereas "specialised engineers" are trained as industrial implementers.

Engineering studies in Latvia are offered on Bachelor, Master and Doctoral level [13]. The Latvia University of Life Sciences and Technologies is one of the leading universities of science and technologies in the Baltic Sea region, specialising in the sustainable use of natural resources aimed at the enhancement of the quality of life in society. Engineering sciences are one of the priority research fields at LLU. Engineering sciences refer to engineering sciences and technologies, as well as to related sub-branches in life sciences, agricultural sciences and medical, and health sciences. The main research activities are conducted in the fields of food technology, sustainable energy, smart vehicles and technologies (mostly focusing on agriculture and forestry), information technology, civil engineering, wood processing, geodesy, environment and water management (including greenhouse gases and agricultural runoff) [14].

The current state of the Russian system of engineering education is difficult to assess. An analysis of the pre-revolutionary system of engineering education makes it possible to identify a number of key 
features that are currently reserved only by the leading universities of the Russian Federation. These features include: development of humanitarian culture, along with scientific and technical knowledge; connection of science and practice; enabling students to creatively develop their field of activity; focus on the practical implementation of completed projects; preparation for professional management of an enterprise. Economic restructuring in the $20^{\text {th }}$ century affected the structure of engineering education. Firstly, mass education was introduced. Secondly, concentration of technologies in state enterprises made managerial and economic functions of the engineer obsolete. Thirdly, the state separated science, industry and education. All of the above adversely affected the quality of engineering education. Nevertheless, it should be noted that several universities have managed to preserve the traditions of the classical concept of engineering education until now. One of such universities is UrFU, the leading scientific and educational centre of the region and one of the largest universities in the Russian Federation. It confers the degree of "engineer" in the following study programs: automation of technological processes and production, design and technological support of machine-building industries, laser technology, mechanical engineering, metallurgy, mechatronics and robotics, metrology, etc.

\section{Materials and methods}

The aim of the present study is to elaborate proposals and recommendations for increasing the students' motivation to study at universities and managing problems of their adaptation. To address this aim, our study has the following objectives: 1 . Analyse theoretical literature on engineering education in various countries and the formation of engineering specialists at the university; 2. Identify characteristic features of engineering education in Europe and Russia; 3. Identify life values of engineering students; personality traits important for professional activities of engineering specialists; factors that affect building social and personal competencies; show the role of the university in addressing the problems of adaptation and motivation for learning experienced by engineering students.

Our research draws on the following methods: analysis of philosophical, managerial, sociological and pedagogical literature; a survey of students pursuing different engineering degrees at the Ural Federal University named after the first President of Russia B. N. Yeltsin (hereinafter UrFU) and the Latvia University of Life Sciences and Technologies (hereinafter LLU); comparative data analysis. To achieve the set aim and objectives, a survey of 627 UrFU students and 127 students of LLU faculties of engineering, has been conducted.

In order to minimise direct contacts between interviewers and respondents, the survey has been conducted via a Google form. A comparative analysis of the results is given in percentage of the students surveyed.

\section{Results and discussion}

The empirical research of the formation of technical specialists at UrFU and LLU has produced the following results.

The survey sample of Russian students (hereinafter UrFU students) includes $43.4 \%$ male and $56.5 \%$ female students. $9.6 \%$ are up to the age of $18,89.3 \%$ are $19-24$ years old, $0.6 \%$ are aged $25-30$, and $0.5 \%$ are over the age of $30.28 .0 \%$ are first-year bachelor students, $38.1 \%$ are $2^{\text {nd }}-$ year bachelor students, $13.6 \%$ are $3^{\text {rd }}$-year bachelor students and $20.3 \%$ are $4^{\text {th }}$-year bachelor students. The sample includes students of chemical technology, biotechnology, nuclear physics and technology, software engineering, construction, electronics and nanotechnology, etc.

The survey sample of Latvian students (hereinafter LLU students) includes $44.9 \%$ male and $55.1 \%$ female students. $92.9 \%$ are aged $19-24,4.7 \%$ are $25-30$ years old and $2.4 \%$ are over the age of $30.48 .0 \%$ are first-year Bachelor students, $23.6 \%$ are $2^{\text {nd }}$-year bachelor students, $14.2 \%$ are $3^{\text {rd }}$-year bachelor students, $13.4 \%$ are $4^{\text {th }}$-year Bachelor students and $0.8 \%$ are $3^{\text {rd }}$-year Master students. The sample includes students of forest science, forestry, forest engineering, computer control and computer science, food technology, civil engineering, landscape architecture, automotive engineering, land surveying, environment engineering, silviculture, environment and water management, machine design and manufacture, etc. 
The students were asked questions regarding their primary motivation for choosing a university, significance of their future profession (system of professional values), professional plans and expectation of engineering students, as well as satisfaction with the chosen field of study and with the university, which is important for the professional adaptation of students.

A comparative analysis of motives for entering the university shows no fundamental differences between UrFU and LLU students: an interest in the profession and prospects of finding a good job prevail among students of both universities (Table 1).

Table 1

Motives of UrFU and LLU students

\begin{tabular}{|l|c|c|}
\hline \multicolumn{1}{|c|}{ Motives } & UrFU & LLU \\
\hline Interest in the profession & $49.3 \%$ & $67.7 \%$ \\
\hline Prospects of finding a good job prevail & $29.8 \%$ & $40.2 \%$ \\
\hline Prestige and authority of the university & $31.1 \%$ & $5.5 \%$ \\
\hline Desire to get a degree, no matter which and where & $21.2 \%$ & $28.3 \%$ \\
\hline To ensure a stable material well-being in the future & $19.9 \%$ & $28.3 \%$ \\
\hline
\end{tabular}

$11 \%$ of UrFU students and $15.7 \%$ of LLU students had a clear understanding of the contents, nature and specificity of professional activities in the chosen field of study when entering the university. $49.8 \%$ of UrFU students and 60.6\% of LLU students had a partial idea thereof. During their university studies, absolute majority of UrFU and LLU students have gained a broader understanding of their future profession (73.2\% and $89.8 \%$ respectively). It is notable that most UrFU and LLU students do not combine their university studies with work (67.8\% and $62.2 \%$ respectively). Among the employed students, the jobs of UrFU students are less related to their future profession than those of LLU students (10.5\% and $27 \%$ respectively).

The students have the following plans after graduation. $65.1 \%$ of UrFU students and $68.5 \%$ of LLU students would like to work or continue their studies (postgraduate or master studies, second higher education) pursuing the occupation for which they are qualified. $12.6 \%$ of LLU students and $6.9 \%$ of UrFU students prefer to set up their own businesses. $12.9 \%$ of UrFU students and $9.5 \%$ of LLU students have no plans for the future yet or their "future in terms of employment is uncertain". This mostly regards first-year bachelor students. The plans of UrFU and LLU students are presented in Table 2.

Table 2

Plans of UrFU and LLU students

\begin{tabular}{|l|c|c|}
\hline \multicolumn{1}{|c|}{ Plans } & UrFU & LLU \\
\hline Educational qualifications: knowledge and professional skills & $64.9 \%$ & $74.8 \%$ \\
\hline Their abilities and personality traits: character, diligence and educability & $60.9 \%$ & $46.5 \%$ \\
\hline Connections, acquaintances and ability to establish contacts & $32.4 \%$ & $4.1 \%$ \\
\hline
\end{tabular}

In their future work, UrFU and LLU students appreciate above all high-paying job opportunities and large profits ( $66.3 \%$ and $48 \%$ respectively), as well as opportunities to build a career and to achieve a high level of professionalism (46.7\% and $44.9 \%$ respectively). UrFU students value possibilities to fulfil their potential (29.8\%) and benefit people (21.9\%). LLU students appreciate working in a good and friendly team $(40.2 \%)$ as well as a creative and interesting nature of work (20.5\%).

Understanding the engineer's personal qualities and building personal, communicative and information competencies are important for professional adaptation of students. Responsibility and stress resistance are thus identified as top priority personal qualities of the engineer (Fig. 1).

These findings are largely in line with a global trend of increasing demand for non-technical and interdisciplinary skills in engineering education. In the European system of engineering education, the evolution of engineering competencies is conditioned by the imperatives of mobility, competitiveness and pan-European identity. Europeanisation of engineering education implies prioritizing interdisciplinarity, student mobility, academic exchanges and expanding non-technical parts of the curricula [4]. Curricula are influenced by internationalisation, increasingly competitive context, social and environmental agenda. UNESCO and the European Union promote ethical and civic dimension of engineering education. Technical skills are complemented by non-technical ones to meet challenges of 
global competition, enable international and inter-sectoral cooperation and foster practical adaptation of technical solutions.

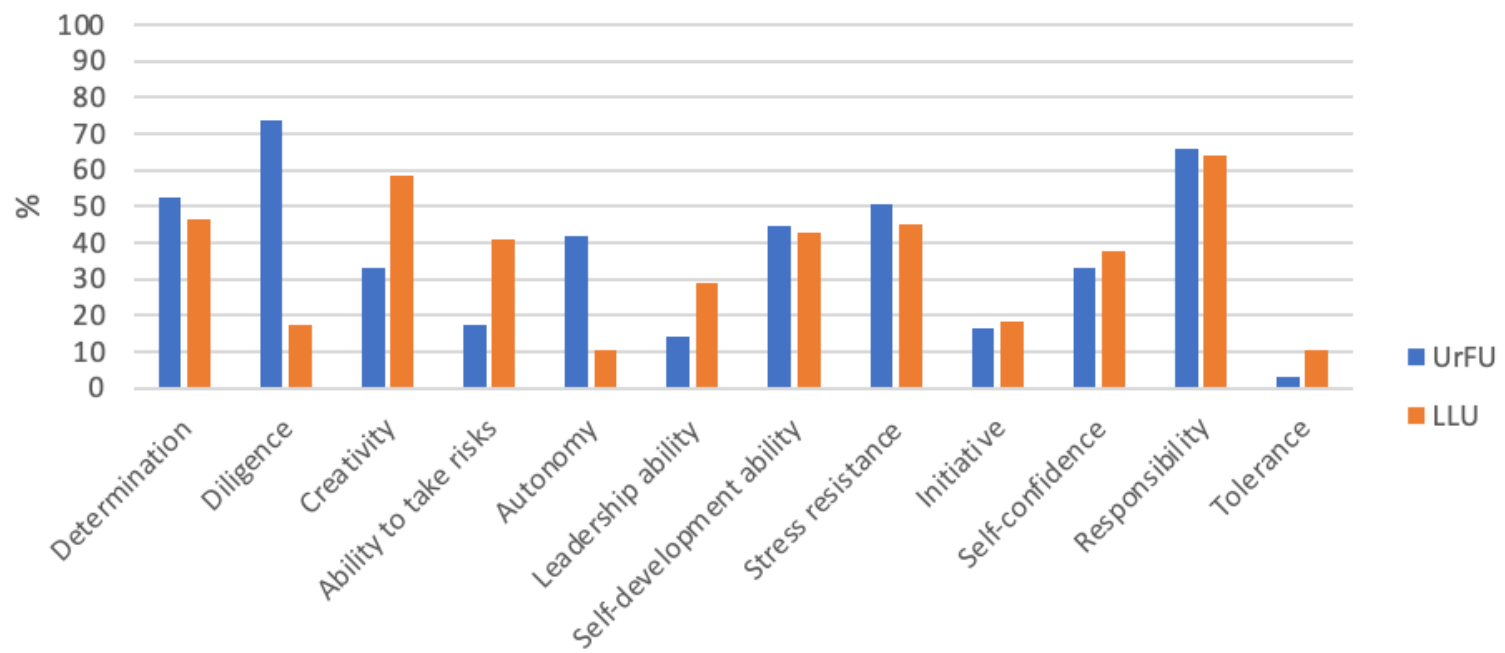

Fig. 1. Personality traits are important for professional activities of engineering specialists

UrFU and LLU students believe that the university profile, field of study and training and education system affect building personal ( $46.4 \%$ and $56.7 \%$ respectively) and information competencies (48.0\% in both surveyed groups). LLU students consider that all of the above affects building communicative competency as well (40.9\%), whereas UrFU students emphasise the training and education system above all $(48.6 \%)$.

In the students' view, the same factors that affect the formation of social and personal qualities are among the most important ones. These include scientific and technical creativity of students, selfmanagement in social and professional engineering activities (54.3\%), cognitive and creative activities in engineering. At the same time, UrFU students give more importance to cognitive and creative activities in engineering, compared to LLU students (51.2\% and $40.9 \%$ respectively), as well as to innovative design and entrepreneurial activities (30.8\% and $16.5 \%$ respectively), whereas LLU students prioritise scientific and technical creativity of students $(63.8 \%$ and $44.8 \%$ respectively), selfmanagement in social and professional engineering activities (54.3\% and $45.3 \%$ respectively) and environmental education $(31.5 \%)$. The role of university and pedagogical education of teachers and tutors in the process of professional adaptation of students is recognised by $24.4 \%$ of UrFU students and $29.9 \%$ of LLU students.

\section{Conclusions}

1. The issues related to the formation of engineers in higher education institutions gain in relevance during the Fourth Industrial Revolution, as employers impose increasingly high standards on the modern engineer, a former student. A university graduate must be competitive in the labour market. The educational organisation represents a key milieu for preparing students for their future profession. Hence, it needs to implement educational programs, taking into account low awareness in the choice of a future profession and distorted views of a future profession held by university entrants and students.

2. Regular research of the problems of motivation for learning and adaptation to a future profession at the university is a prerequisite for the formation of a highly qualified specialist in the field of engineering. Monitoring of problems will contribute to the adaptation of students to their future profession, as they pursue their curriculum. Certainly, countries differ in characteristic features of engineering education; so do Latvia and Russia where students of both universities that have participated in the present research show interest in obtaining an engineering degree and, to varying degrees, manifest a desire to pursue occupations for which they are qualified after graduation (65.1\% of UrFU students and $68.5 \%$ of LLU students). The most UrFU and LLU students do not combine their university studies with work (67.8\% and $62.2 \%$ respectively). 
3. In order to address the identified problems related to the need to expand the knowledge of the nature, contents and specificity of the future profession while studying at the university, it is necessary to carry out career guidance work among senior students so as to provide a clear understanding of the national and regional labour markets; to use project-based learning opportunities; to develop a practice-oriented teaching, which consists in creating conditions for building a wide range of personal, communicative and information competencies through practices, internships, workshops and field trips; to form personal qualities necessary for the future profession and in the labour market at large.

\section{References}

[1] Сапрыкин Д.Л. Инженерное образование в России: история, концепция, перспективы (Engineering education in Russia: history, concept, perspectives). Высшее образование в России: Higher Education in Russia, 2012, No 1, pp. 125-137. (in Russian)

[2] Jobs of Tomorrow Mapping Opportunity in the New Economy. World Economic Forum. 2020. [online] [10.03.2021]. Available at:

http://www3.weforum.org/docs/WEF_Jobs_of_Tomorrow_2020.pdf

[3] Abdulwahed M., Hasna M.O. The Role of Engineering Design in Technological and 21st Century Competencies Capacity Building: Comparative Case Study in the Middle East, Asia, and Europe. Sustainability, vol. 9, No 4, 2017, pp. 1-23.

[4] Downey G.L., Lucena J.C., Moskal B.M. etc. The Globally Competent Engineer: Working Effectively with People Who Define Problems Differently. Journal of Engineering Education, 2006, vol. 95. No 2, pp. 107-122.

[5] Dudin M.N., Bezbakh V.V., Frolova E.E., Galkina M.V. The Models of Higher Education in Russia and European Countries at the beginning of the XXIst century: the Main Directions of Development. European Journal of Contemporary Education, 2018, vol. 7, No 4, pp. 653-667.

[6] Коробцов А.С. Качество инженерного образования: лозунги и реальность (The quality of engineering education: slogans and reality). Инженерное образование: Engineering Education, 2020, No 27, pp. 27-36. (In Russian)

[7] Коробцов А.С. Обоснование профессиональных профильных компетенций в инженерном образовании (Justification of professional profile competencies in engineering education). Инженерное образование: Engineering Education, 2019, No 26, pp. 28-34. (In Russian)

[8] Васильев В.И., Шарыпов А.В., Савельев А.В., Рыбин Н.Н. Анализ организации научноисследовательской деятельности студентов в условиях развития цифровых технологий (Analysis of the organization of research activities of students in the context of the development of digital technologies). Инженерное образование: Engineering Education, 2019, No 26, pp 66-74. (In Russian)

[9] Соловьев В.П., Перескокова Т.А. Формирование социально-личностных качеств инженера (Formation of social and personal qualities of an engineer). Инженерное образование: Engineering Education, 2019, No 25, pp. 119-129. (In Russian)

[10] Briede B., Popova N. Self-directed learning of university engineering students in context of Fourth Industrial Revolution. 19th International Scientific Conference "Engineering for Rural Development" Proceedings, vol. 19, May 20-22, 2020, Jelgava, Latvia, pp. 1594-1600. [online] [12.03.2021] Available at: http://www.tf.llu.lv/conference/proceedings2020/Papers/TF405.pdf

[11] McGrath D. The Bologna Declaration and Engineering Education in Europe. Institution of Engineers of Ireland, 2000. [online] [12.03.2021] Available at: http://mie.uth.gr/labs/ltte/grk/quality/..\%5Cquality\%5Cbologna_declaration_engenee.pdf

[12] Lemaître D. Current developments in the French engineering education system. European Journal of Engineering Education, vol. 42, No 2, 2016, pp. 131-141.

[13] Bachelor of Engineering (B. Eng.) in Latvia. [online] [16.03.2021] Available at: https://www.bachelorsportal.com/countries/degrees/537133072/bachelor-of-engineering-inlatvia.html

[14] Latvia University of Life Sciences and technologies developemnet strategy 2015-2022. [online] [16.03.2021] Available at: https://www.llu.lv/sites/default/files/202012/StrategijaENG_8_12_2020.pdf 